\title{
År 1918 som en röd tråd genom ett helt författarskap
}

Anna Bondestam och inbördeskriget

I en nyckelscen i Anna Bondestams roman Stadens bröd (ig6o) för två av centralgestalterna, Mia och Jonas, en dialog om språkfrågan, ett dominerande politiskt tema i Finland år 1905. Handlingen i romanen är förlagd till Jakobstad - en stad i snabb utveckling under den intensiva industrialiseringen kring sekelskiftet I900. Jonas är backstugusittarens son som blivit sjöman. Mia arbetar på den lokala tobaksfabriken efter flera år som piga hos herrskapet Öhrgren. I stan talar alla gamla "stassbor" om hur mycket bättre det var förr, innan det kom många finnar till stan.

- På sista tin, sa hon sen, har di jär i stan börja prat så mytje om hur e är ti vara svensk å att svenskan ska håld ihop. Men ja brukar tänk att vaför sku jag håld ihop med fru Öhrgren? I hennas ögon ä jag bara en dumban pigo som ho kan bära sig åt mot hur som helst - ja vet he för he har hänt. [...]

Plötsligt böjde hon sej fram över bordet och såg på honom med gäcken i ögonen:

- Tänk om jag sku gå till fru Öhrgren å säj: goda kamrat, hur står e til ida?

De brast i skratt samtidigt och skrattade så att tårarna rann. ${ }^{1}$

I samma bok utspelar sig en scen där Mia rasar över fru Öhrgrens beteende i ett samtal med Vicki Byman, stadens egensinniga skomakare. På tobaksfabriken har arbetarkvinnorna en enda fridag om året,

I. Anna Bondestam, Stadens bröd, Helsingfors: Holger Schildts förlag I960, s. 28I. 
förutom söndagarna. Det gavs en ledig dag mitt i sommaren under bärtiden. Då står fabriken och kvinnorna tjänar sin dagslön genom att plocka blåbär till försäljning.

Mia har gått för att sälja blåbären till sin gamla matmor. Fru Öhrgren lyckas genom skickliga manövrar få Mia att sälja bären för en struntsumma - vilket Mia märker först då hon hemma vågar titta på slanten som stoppats i näven på henne. Då sköljer harmen över henne.

- Hon fråga ju int ens, skrek Mia. Hon ljög att hon int behöva döm å så gav on va on vila.

Vicki skrockade sakta.

- Ja, sa han med oväntad fryntlighet, hon ä ju doter ti kommerseråde.

Mias läppar började darra.

- För he har on full int rätt ti göra va on vill.

- Hm, sa Vicki. - Hon har nog blivi lärd ti tro he. ${ }^{2}$

Stadens bröd och Vägen till staden ${ }^{3}$ visar tydligt på drivkraften i Anna Bondestams hela författarskap. Hon tecknar bilden av svenskspråkig arbetarklass i småstadsmiljö och bygger framställningen på efterforskning men också personliga källor - hon är själv stadigt rotad i arbetarkvarteren i Jakobstad. Bondestam har en politisk agenda samtidigt som hon noggrant ser till att intrigen är trovärdig.

Att hon inte tagit sig an någon lätt uppgift bekräftas av Claes von Rettig i en recension av Stadens bröd i Aftonbladet, där han granskar romanens - och författarens - position i den finlandssvenska litteraturen.

Det nya blodet i finlandssvensk litteratur har inte bara bestått av borgerlighetens självkritiker: Kihlman och Donner. Under 5o-talet har en bred proletärlitteratur vuxit fram. Den kommer från bondelandet Österbotten, där det svenska arbetarinslaget är starkt. Men det är en expansion med komplikationer. Utöver sin flerdubbla minoritetsställning och sina usla ekonomiska möjligheter har gruppen att utstå dels nedlåtenheten från de egna högre klasserna, dels medvetandet om sin trettioåriga eftersläpning till den svenska proletärdiktningen

2. Bondestam, Stadens bröd, s. I68.

3. Anna Bondestam, Vägen till staden, Helsingfors: Holger Schildts förlag 1957. 
och dess mäktiga kvalitet. Någon större stimulans torde inte heller utgå från Linna och hans alltslukande monopolisering av Finlands proletära historia. Skäl till mindervärdeskänslor finns alltså, och ännu har få kommit över dem. ${ }^{4}$

Anna Bondestam fick år 1963 Svenska Finlands folktings förtjänstmedalj. År 1977 promoverades hon till hedersdoktor vid Helsingfors universitet, år 1979 fick hon Karl Emil Tollanders pris och Tollanderska medaljen. Hon utsågs till hedersmedlem i Finlands svenska publicistförbund år 1982. Hon prisbelönades med Pro Finlandia-medaljen I989.

Trots rader av utmärkelser och priser, goda recensioner och en stadigt befäst position som den finlandssvenska arbetarrörelsens egen historieskrivare led Anna Bondestam livet igenom av mindervärdeskomplex. Det framkommer tydligt bland annat i de djupgående intervjuerna i samlingen Finlandssvenska författarintervjuer. ${ }^{5}$

Komplexen bottnar i olika skikt i hennes livsberättelse. Som finlandssvensk författare i mitten av i9oo-talet sticker Anna Bondestam ut. Hon kommer från arbetarklassen, är österbottning, socialdemokrat och kvinna i en epok då de flesta författare har en helt annan social bakgrund. Därtill skriver hon epik och skildringar av bygdernas människor under en tidsperiod då en modernistisk stil och självbespegling är i ropet.

I en av intervjuerna säger Bondestam att hon upplevde att kollegerna i Finlands svenska författareförening betraktade henne som en andra klassens författare:

Jag har alltid upplevt mig som ensam. Jag var ju så annorlunda, skrev så annorlunda.Jag hade ju en alldeles annan motivation än alla andra. Och jag vet att alla tyckte att det var alldeles onyttigt, epik, det var ju så gammaldags, ingenting att syssla med mera. ${ }^{6}$

4. Claes von Rettig,"Anna Bondestam, Österbotten", Aftonbladet $\mathrm{I} 3 / 3$ I96r.

5. Samlingen Finlandssvenska författarintervjuer, SLSA rog9, intervjuare Inger Bäcksbacka, Svenolof Karlsson, Ingmar Svedberg och Inga-Britt Wik, Historiska och litteraturhistoriska samlingen, Svenska litteratursällskapet i Finland (SLS arkiv), Helsingfors.

6. Ibid. 


\section{DE FORMATIVA ̊̊REN}

I Anna Bondestams livsberättelse urskiljer man en röd tråd. Hon försöker aldrig klippa av den. Tråden är bokstavligen röd - hon föddes in i socialdemokratin och höll sig till den livet ut. Trådens båda ändar, början och slutet, finns i Jakobstad.

Anna Elfving föddes i arbetarstadsdelen Skata till ett par resursstarka föräldrar. Hon föds in i berättelsen som utgörs av den samhällsutveckling som vårt land genomgick under I90o-talet. Hon är en del av denna berättelse; hon upplever den och hon skriver om den. Hennes liv sträcker sig genom nästan hela I900-talet, men hon återkommer ständigt till de mest formativa åren, seklets ungdom. Uppväxten präglades av de lyskraftiga föräldrarna. Otto och Lina Elfving var starka personligheter. För Ottos, plåtslagarens, del räckte lyskraften till att ge honom en plats i riksdagen, där han som socialdemokrat invaldes I9I9. Tobaksarbeterskan Linas styrka räckte till ett långt liv, hon levde till 99 års ålder, ständigt nära dottern, med en vitalitet som syntes i både ord och handlingar.

Föräldrarna kom att ta en betydande plats i Anna Bondestams liv och författarskap. Hemmets värderingar, särskilt faderns livssyn, formade henne. Otto var ideologiskt övertygad. Han var het i tanken men inte i gärningar, ville övertyga genom argumentation men inte genom att slå näven $\mathrm{i}$ bordet. I hemmet rådde en humanistisk anda som bottnade i en svag tilltro till auktoriteter. "Tänk själv, lärde han mej”, säger Bondestam. ${ }^{7}$ Otto Elfving själv blev däremot, i kraft av sitt intellekt, en auktoritet. Han var en ledare; många ville samtala med Otto i hans hem. Anna Elfving lyssnade till politiska diskussioner ända från barnsben. Hon lärde sig tidigt att aldrig slentrianmässigt acceptera ett konventionellt tänkande. Då hon var tio år utbröt inbördeskriget, ett krig som fick återverkningar i decennier av Finlands historia. Månaderna före hennes elvaårsdag i april I9ı8 blev det klart för Anna att det spelade en roll var man stod politiskt och att denna positionering kunde påverka hela livshållningen.

7. Samlingen Finlandssvenska författarintervjuer, SLSA ro99, SLS arkiv, Helsingfors. 
I9I8 har präglat mig för livet. Inte så att det konserverade hatkänslor, men det kom att binda mej vid mina föräldrar och deras meningsfränder med så starka band av lojalitet och sympati att de har hållit livet ut. Självfallet har jag senare ur min politiska hållning mönstrat ut mycket av den religiöst färgade socialism som var mina föräldrars. ${ }^{8}$

\section{ROMANEN KLYFTAN VÄXER FRAM}

Upplevelserna år I9I8 tog sitt tydligaste litterära uttryck nästan trettio år efter själva kriget. År 1946 gav Anna Bondestam ${ }^{9}$ ut romanen $K_{\text {Klyfan }}{ }^{10}$, allmänt betraktad som en av de första skildringarna på svenska av inbördeskriget ur de rödas perspektiv. ${ }^{11}$ Vägen till att skriva en roman som Klyftan var dock långt ifrån spikrak. Anna hade lämnat Jakobstad hösten 1925 för att studera vid Helsingfors universitet. Plåtslagarens och tobaksarbetarens dotter begav sig ut på en regelrätt klassresa då hon lämnade småstaden. Helsingfors och dess vänsterintellektuella kretsar blev hennes hem de följande dryga 50 åren. Sin författardebut begick Anna Bondestam år 1936 med småstadskomedin Panik i Rölleby. ${ }^{12}$

Men det är först romanen Lågt $i$ tak $k^{13}$ år 1943 som får status av ett pionjärverk: en finlandssvensk arbetarskildring. Den var ett avgörande steg för det fortsatta författarskapet, och Bondestam fick nu ett första grepp om sin förmåga att skildra folket i svenskbygden. I en intervju kommenterar Bondestam beslutet att skriva en roman om finlandssvensk arbetarklass: "Nångång skulle det väl bli så att jag blir en social författare, om jag överhuvudtaget skulle bli en författare. Allt var ju bäddat för det. Hela min uppfostran och allting." ${ }^{14}$ Lågt $i$ tak förebådade Klyftan men också Vägen till staden och Stadens bröd.

8. Anna Bondestams arkiv, odaterat föredrag om det egna författarskapet, Jakobstads museum, Jakobstad.

9. Anna Elfving tog makens efternamn Bondestam vid giftermålet 1936.

Io. Anna Bondestam, Klyftan, Helsingfors: Holger Schildts förlag I946.

II. Se bl.a. Thomas Warburton, Åttio år finlandssvensk litteratur, Helsingfors: Schildts I984, s. 307 .

I2. Anna Bondestam, Panik i Rölleby, Helsingfors: Holger Schildts förlag 1936.

13. Anna Bondestam, Lågt i tak, Helsingfors: Holger Schildts förlag I943.

I4. Samlingen Finlandssvenska författarintervjuer, SLSA ıo99, SLS arkiv, Helsingfors. 
I oktober 1944 går fadern Otto bort i lungsot och hans död sätter igång en mental process hos dottern. På Helsingfors gator och torg gläder man sig åt freden efter fortsättningskriget men i Bondestams inre börjar ett gammalt krig sakta utspela sig igen. Minnena från I9I8, då hon var en tioårig brådmogen skolflicka och rädd för att pappan skulle dödas, väcks till liv: "Då dog han varje natt för mig, för min inre syn. I flera månaders tid." ${ }^{15}$ Bondestam kallar det den dolda terrorn. Den drabbade ett oskyldigt barn som kväll efter kväll sjönk ner i bottenlös oro över att fadern - ordförande för stadens finska arbetarförening - skulle bortföras av de vita och dödas.

Bondestam ville behandla sina erfarenheter av rädslan och göra dem allmängiltiga. Hon hade levande minnen av en dramatisk period i landets historia och hon behärskade sitt hantverk. Men för att skriva en bok som Klyftan i mitten på I940-talet krävdes det mera än så; det krävdes mod. Bondestam tänkte skriva dokumentärt och blottlägga sina personliga känslor av utanförskap. Dessutom tänkte hon bryta ny mark i den finlandssvenska litteraturen med en skildring av 1918 ur de rödas perspektiv. Hennes kapacitet som författare skulle prövas på allvar. I ett efterhandsperspektiv kan det förefalla givet att Anna Bondestams stora litterära framgångar röntes inom detta tematiska område. I det mentala klimat som rådde i Finland under 1940- och I950-talen var framgången dock långt ifrån förutsägbar.

Avgörande för Bondestams utveckling till författare var att hennes föräldrar hade haft insikt och råd att välja en tillräckligt krävande skolgång för dottern. Men bildningsgången skuggades av hennes sociala bakgrund. Redan från den första klassen har Bondestam tydliga minnen av klasskillnader: I "Tant Svanlunds skola" lät tant Svanlund eleverna veta att det var skillnad på folk och folk, under tidsperioden när skillnaderna redan började skifta i vitt eller rött. ${ }^{16}$ Ännu tydligare blev skiljelinjerna i läroverket hösten I9I8.

Anna Bondestam har i intervjuer och egna föredrag lyft fram att Klyftan ska ses som ett slags dokumentation av hennes egna barndomsminnen från den tid som beskrivs i romanen. Hon ställde själv

I5. Ibid.

I6. Ibid. 
ett sanningskrav på det hon beskrev. ${ }^{17}$ Hon skriver självbiografiskt ur ett barns perspektiv. Berättarrösten, den tioåriga flickans, är Anna Bondestams egen. Boken utspelar sig år I9I8 i Jakobstad; i romanen berörs bland annat känsliga händelser som de vitas avrättning av sju män vid porten till tobaksfabriken. I centrum står Bondestams alter ego Rut och hennes tankevärld. Trots det skenbara lugnet i småstaden blir det under krigets gång allt klarare för Rut att hennes familj befinner sig i en utsatt position. Ingen uttalar det klart, men det som händer familjens vänner, den rädsla hon uppfattar hos modern och den tryckta stämningen i hemmet förmedlar en bild som gör henne skräckslagen - för i den ingår ett hot mot hennes föräldrar.

I Klyftan bygger huvudpersonen Ruts tankar på Bondestams egna erfarenheter från läroverket:

I skolan kröp hon in i tystnadens pansar och bara lyssnade och iakttog. Här till och med mer än någon annanstans. För här, det visste hon ju, befann hon sig mitt inne i fiendelägret.

Ibland kom det också ett glåpord singlande och träffade henne rakt i ansiktet. Då vände hon ryggen till och flydde som en hare. Och sedan gick hon och väntade i ett slags panisk skräck. Men det kom aldrig någon fortsättning, hon blev aldrig tjudrad vid någon offentlig skampåle som Den Föraktade Fienden. Men ändå upphörde hon inte att frukta.

[...] Men ibland gick hon och önskade så intensivt att hon hade fått vara en av dem igen, att hon helt enkelt sviktade. Då lyssnade hon inställsamt när de talade om kriget, om de vitas hjältedåd och de röda banditernas grymheter. Lyssnade och teg, fegt och med intresserad uppsyn. Gjorde sig till och kråmade sig och kände sig ynklig och ville gråta. Var en liten tragikomisk pajas och visste det själv på något vis. Sedan skämdes hon och gick och rabblade för sig själv: de ljuger, de ljuger de ljuger. Men det hjälpte inte stort, för hon visste

I7. Se vidare Pia Heikkilä, Anna Bondestam. Det röda Svenskfinlands röst, Skrifter utgivna av Svenska folkskolans vänner, volym I95, SFV:s biografiserie nr 4, Helsingfors: Svenska folkskolans vänner 20I3, s. IIO-III. 
ju att hon aldrig hade vågat säga det högt och det kom henne att skämmas ännu mera. ${ }^{18}$

Utåt syntes knappast något av den tioåriga flickans inre pina. I läroverket dominerades klassen i själva verket av arbetarbarn. Men andan i skolan var vit. Värderingarna formulerades av borgerligt sinnade: lärarna, stadsbarnen och böndernas barn från landsbygden, de flesta självklart rotade i den svenska, ägande klassen. Att i denna omgivning vara dotter till den finska arbetarföreningens ordförande satte livslånga spår i Anna Bondestam. Hon var en god elev. Duktigheten var hennes försvar. Hon lärde sig att stålsätta sig mot den påträngande normen, utan att göra väsen av sig. De egenskaperna satt kvar då Bondestam 20 år senare skrev Klyftan. Bondestams sätt att skriva tog en ny riktning; hon skrev med större eftertanke än tidigare. Att bearbeta texten hårt blev ett slags förberett försvar inför annalkande anfall. "Jag trodde ju att det skulle bli en förskräcklig storm mot den, men det blev det ju aldrig. Men jag trodde det. För att jag skrev om I9I8."19

Genom att ge ut Klyftan tycker Bondestam att hon ger sig in i en politisk debatt. Hon är inte den retoriskt utåtriktade typen, ställer sig inte på barrikaderna. Inte heller som skildrare av I9I8 tar hon till brösttoner. I stället är det hennes lågmälda säkerhet som får beröm då Klyftan läses av kritikerna hösten 1946. Bertel Kihlman i Nya Argus säger att hon är värd erkännande för den lugna och säkra behärskning, den genomlysta objektivitet som präglar skildringen från den första sidan till den sista. ${ }^{20} \mathrm{I}$ Jakobstads Tidning prisar Hans Hartell:

författarens psykologiska skildring som gör boken till en konstnärlig helhet, som jämte den vårdade, strama och frasfria stilen gör att man måste ge den ett mycket högt betyg, oavsett hur man än reagerar mot de åsikter och teser som förs fram på dessa sidor. ${ }^{21}$

I8. Bondestam, Klyftan, s. 40.

I9. Samlingen Finlandssvenska författarintervjuer, SLSA ı099, SLS arkiv, Helsingfors.

20. Bertel Kihlman,"Anna Bondestams nya bok", Nya Argus I5/II 1946.

2I. Hans Hartell, "Fyra finländska författarinnor. Ett axplock ur bokfloden", Jakobstads Tidning I4/II 1946. 
P.O. Barck i Hufoudstadsbladet slår fast att "inbördeskrigets upplevelser var smärtsamma för båda sidor och det är inte längre angeläget stanna vid dess politiska aspekt. Det har Anna Bondestam inte heller gjort”22. En del recensenter har behov av att näpsa författaren. Einar Holmberg i Åbo Underrättelser påminner om att "vad hon (Rut) upplevde på den röda sidan av den skiljande linjen är för resten precis det samma som 'de vita' upplevde på den av de röda behärskade delen av landet." ${ }^{23}$ Gudrun Mörne i Arbetarbladet är en av de få som sätter ner foten:

När man läser Klyftan kan man inte undgå reflexionen att Anna Bondestam är den första och enda författare som på svenskt språk i Finland berört inbördeskrigets tid utifrån arbetarklassens erfarenheter och inställning. Utom Diktonius förstås, som ju snuddat vid denna motivkrets här och var i sin diktning. Vi har faktiskt just inga svenskspråkiga författare ur arbetarklassen $\mathrm{i}$ vårt land mer än de. ${ }^{24}$

Enstaka recensenter förmådde koppla samman barndomsskildringen med det politiska, som Olof Enckell i Nordisk bokkalender:

I Klyftan är den psykologiska synvinkeln så intimt förenad med en social, att boken fängslar läsaren inte bara som en förtjusande barnskildring utan även som en lärorik analys av en given samhällsmiljö. Även tidshistoriskt är romanen betydelsefull: den låter I9I8-års svåra och tragiska medborgarkonflikt avspegla sig i ett arbetarbarns föreställningsvärld och mognadsprocess. Litteraturen om denna avgörande brytningspunkt i det moderna Finlands historia har varit lika sparsam som ensidig, och inte minst därför är Anna Bondestams kloka och fint nyanserade berättelse värd särskild uppmärksamhet vid en granskning av fjolårets prosaskörd. ${ }^{25}$

22. P.O. Barck, "I skuggan av skräcken", Hufoudstadsbladet 25/10 I946.

23. Einar Holmberg,"Barnet inför skräcken", Åbo Underrättelser 27/II 1946.

24. Gudrun Mörne,"Ett barn i skräckens århundrade", Arbetarbladet 25/10 I946.

25. Olof Enckell,"Finlandssvensk skönlitteratur", Nordisk bokkalender: en översikt över bokutgivningen i Norden 1946, Bengt Åhlén (red.), Stockholm: Biblioteksböcker I947. 
Klyftan gavs ut i nytryck i början på i96o-talet, då slussarna öppnats för vänsterlitteratur. $\mathrm{Nu}$ lästes romanen med något andra ögon. Kurt Sanmark skriver i Hufoudstadsbladet:

'Klyftan' hör till den ytterst sparsamma skönlitteratur som vi har på finlandssvenskt håll om händelserna år 1918 - ett förhållande i sig värt att notera. Jag har ibland reflekterat över denna brist - är det så att ärren från kampen ännu är inflammerade för den generation som upplevde den eller växte upp i dess skugga eller har den samband med att vår författarkår ända till senaste tid i huvudsak rekryterats från de samhällslager som representerar den segrande sidan? Faktum är att en bredare skildring av inbördeskriget - eller frihetskriget, hur man nu kallar det - i finlandssvensk miljö aldrig sett dagen, trots att man tycker att temat skulle ha legat nära till hands. ${ }^{26}$

Klyftan har kallats en modern klassiker och har tryckts i 26 ooo exemplar. Att den är spridd, läst och älskad av många står klart, men mottagandet blev en besvikelse för Bondestam. Hon hade förberett sig på debatt och mothugg. Bondestam ansåg från första början att Klyftan är en politisk roman. Att de häftiga reaktionerna uteblev lämnade kvar en frustrerad känsla av att inte ha blivit förstådd. ${ }^{27}$

\section{ARBETARKLASSEN SOM LITTERÄRT TEMA}

Finlandssvenska författare kom, vid den tid då Anna Bondestam debuterade, inte från arbetarkvarter i österbottniska småstäder. Majoriteten hade i stället en bakgrund i huvudstadens bildade hem. Enligt en undersökning år 1992 tillhörde 90 procent av medlemmarna i Finlands svenska författareförening år 1920 antingen överklassen eller den övre medelklassen. ${ }^{28}$ Anna Bondestam satt visserligen inte och skrev i fotogenlampans sken på kvällarna efter en lång arbetsdag på fabriken - i den meningen befann hon sig inte längre i en arbetarmiljö när hon skrev sina böcker. Men i en arbetarklassmiljö hörde hon hemma

26. Kurt Sanmark, "Barn år 1918”, Hufoudstadsbladet 23/4 I96r.

27. Se vidare Heikkilä, Anna Bondestam, s. II6.

28. Lena Långbacka \& Benita Alanne, Finlandssvenskt författarskap. Kåren och villkoren. Två undersökningar, Åbo: Åbo Akademi 1993. 
mentalt och hon tampades med klassresenärens våndor under hela sitt författarskap. I Söner av nederlaget noterar Sven Willner att den sociala bakgrunden ofta har betydelse för en blivande författare eller konstnär:

Det är tämligen ofrånkomligt, att den kulturella bakgrund som en ärvd förmögenhet, 'bildat umgänge' och en traditionell skolgång brukar föra med sig, vanligen ger upphov till en större säkerhet när det gäller att behärska också de konstnärliga uttrycksmedlen. ${ }^{29}$

Bondestam var själv medveten om sitt utgångsläge.

Jag har en helt annan bakgrund än de flesta av mina generationskamrater bland de finlandssvenska författarna. Jag kommer från en renodlad arbetarmiljö och betraktar mig som en produkt av den. Men jag bör kanske tillägga att jag inte har några bittra erfarenheter av min ursprungsmiljö, snarast tvärtom. ${ }^{30}$

Efter Klyftan dröjer det över tio år tills Bondestam litterärt återkommer till arbetarklasstemat. Att skönlitteraturen är en kraft, mäktigare än den historiska forskningen, märker Bondestam medan arbetet med Vägen till staden (1957) och Stadens bröd (1960) pågår. Väinö Linnas storslagna torpartrilogi utgiven åren 1959-1962 gav upphov till bred debatt och bidrog till en förändrad syn bland annat på händelserna år I9I8. Också Bondestam bygger i Vägen till staden upp en berättelse kring de obesuttnas dröm om ett bättre liv. Två av huvudpersonerna, Mia och skomakare Vicki Byman, har formats med bekanta karaktärer för ögonen: Bondestams föräldrar Lina och Otto Elfving. ${ }^{31}$ I Mia skapar Bondestam en kvinnogestalt som var otypisk för tiden, med osedvanlig tåga och en vilja att ifrågasätta. Denna förmåga utvecklas under handlingens gång, inte minst under inflytande av skomakaren Vicki Byman - den okonventionell tänkande, intellektuellt lagda arbetaren.

29. Sven Willner, "Söner av nederlaget", Söner av nederlaget och andra essäer, Ekenäs: Ekenäs tryckeri aktiebolags förlag 1979.

30. Anna Bondestam, föredrag vid Jyväskylä universitet på I970-talet, Anna Bondestams arkiv, Jakobstads museum, Jakobstad.

3r. Samlingen Finlandssvenska författarintervjuer, SLSA ro99, SLS arkiv, Helsingfors. 
Tre år senare kommer uppföljaren Stadens bröd. Som den centrala pelaren i romanbygget reser sig Strengbergs tobaksfabrik som ger stadens invånare arbete och bröd. Från landsbygden strömmar arbetskraften till och stadens språkförhållanden förändras - det tidigare helsvenska Jakobstad blir tvåspråkigt. Till sin intrig är Stadens bröd en berättelse om småstadsliv. Samtidigt är den en politisk roman som undersöker orsaken till att folket revolterar. Stadens bröd är en spegling av ett skiktat samhälle där de underkuvades vördnad för auktoriteter förhindrar en social utveckling. Klasskillnaderna syns inte enbart i materiell levnadsstandard utan också i skillnader i livshållning, där den överordnade på ett närmast självklart sätt utnyttjar den som tilldelats en underdånig position.

Parallellt med klasskillnaderna genomsyras Stadens bröd av språkfrågan. Vid tiden för storstrejken I905 och kampen för allmän och lika rösträtt uppstår ett dilemma för stadens svenska arbetarbefolkning. Ska den, för språkets skull, ställa sig på samma sida som det svenska herrskapet eller ska den solidarisera sig med de finska arbetarkamraterna? Då Jonas i Stadens bröd ska ansluta sig till demonstrationståget i samband med storstrejken går han in i ledet först när han får syn på dem som står lägst på den sociala rangskalan. De är finnar. Bondestam kommenterar i en intervju:

Det är ju så naturligt för honom. Han kommer från en backstuga och har upplevat det verkliga eländet. De här har också kommit från en backstuga, det ser han på dem, de är lika honom. Då spränger han alla språkbarriärer och allting. [...] Precis likadant som då jag själv deltog i studentdemonstrationerna i slutet av 1920-talet i Helsingfors, jag gick med i den svenska men när jag såg den finska så tänkte jag att det är ju här jag hör hemma, där var folket som liknade min bakgrund, det var alldeles naturligt. ${ }^{32}$

Bondestams närhet till det finska språket är ett viktigt arv från fadern Otto. Att den beundrade fadern talade finska - ytterligare en ingrediens som skiljde den elfvingska familjen från Jakobstads svenskspråkiga bönder och borgare - har haft en stor betydelse för Bondestam.

32. Ibid. 
Det finska står ju mig nära. Jag har aldrig haft den inställning som många representanter för min generation har haft, att man på något sätt var överlägsen för att man var svensk. Helt enkelt därför att i den miljö som jag växte upp var det snarast min pappa som var överlägsen, i den svenska miljön klarade han sig både med intellekt och personlighet. ${ }^{33}$

Stadens bröd kom att bli den av Bondestams böcker som recenserades flitigast. I Hufoudstadsbladet skriver Jörn Donner: "Vissa prosaverk förefaller på grund av sin inre natur mer än vanligt nödvändiga, som rening och uppgörelse. Sådana böcker verkar förnyande på vår verklighetssyn." Donner ser det politiska i romanen och hyllar författarens skicklighet:"Hon vill förklara och förstå framom att fördöma. Därför blir personerna utomordentligt trovärdiga." ${ }^{34}$ I Jakobstads Tidning tonar recensenten Hans Hartell ner det politiska budskapet och ger poäng för att Stadens bröd trots temat inte är någon enögd tendensroman. Tendenslösheten hyllas av flera andra recensenter: "den har inte karaktären av en stridsfackla kastad mot samhällsbråtet", "ingen politisk pamflett", "utan uppblåst patos" 35 . Men alla håller inte med. I Vasabladet kallas Stadens bröd i mycket"en tendensroman - en socialskildring om än i det väsentliga kanske ändå endast en roman, stor nog att bära fram sig själv." ${ }^{36}$ Också Sven Willner i Västra Nyland ser att” Anna Bondestam åtminstone delvis är ute i sociala ärenden men hon är ingen fanatiker." 37

\section{POPUL ÄRHISTORIKER}

Drygt I5 år senare verifierar Bondestam i populärvetenskaplig form den bild av Jakobstads förvandling till industristad och denna utvecklings verkningar för staden och stadsborna, som hon skönlitterärt tecknat i Vägen till staden och Stadens bröd. Historiken En stad förvandlas ${ }^{38}$ är

33. Ibid.

34. Jörn Donner, "Stadens bröd", Hufvudstadsbladet 29/II I960.

35. Hans Hartell,"Ett småstadsepos. Om Stadens bröd", Jakobstads Tidning II/I2 I960.

36. Alf Snellman, "Stadens bröd - Bondestam", Vasabladet 2I/12 1960.

37. Sven Willner,"Mia och storstrejken", Västra Nyland 8/12 I960.

38. Anna Bondestam, En stad förvandlas, Jakobstad: Jakobstads svenska arbetarförening rf 1978 . 
ett beställningsarbete av Jakobstads svenska arbetarförening. Boken behandlar stadens historia ur ett folkligt perspektiv. Den är ett paradexempel på den sakprosa som Anna Bondestam övergått till att skriva efter Stadens bröd, som blev hennes sista roman. Hon är ingen historiker med akademiska ambitioner och kallar inte sina arbeten vetenskapliga. Hon etablerar i stället en personlig stil där humor och ironi blir kännetecken och skildringarna får litterära drag. Hennes linje är att inte dölja var hon har sina sympatier - vilket inte betyder att hon ger avkall på fakta. Hon är pedantisk i sin kontroll av källor.

En stad förvandlas gillas av de flesta recensenter. Men Bondestams polemiska stil möter också skarp kritik. Maj-Britt Höglund i Hufvudstadsbladet ser ett vinklat dokument och menar att Bondestam förfaller till att upprätthålla en felaktig och konstgjord klyfta mellan samhällsklasserna. ${ }^{39}$ Dennis Rundt i Vasabladet ser däremot Bondestams perspektiv som en förtjänst:

Samtidigt som hon gör upp med den historieskrivning som betonat några få stormäns betydelse och välgärning, kompletterar hon den historiska bilden av Jakobstad på ett sätt som visar hur begränsad och inkrökt vår historieskrivning både har varit och fortfarande är. ${ }^{40}$

Då Bondestam ger sig in på att gestalta den finlandssvenska arbetarrörelsens historia beträder hon jungfrulig mark. Nästan ingenting finns skrivet. Standardverket är Fritjof Sundqvists femtioårshistorik över Finlands svenska arbetarförbund från 1949 - och det är så gott som allt som finns. Händelserna r9ı hade tabubelagt forskning om arbetarrörelsen. Lika lite efterfrågades oavhängig forskning om inbördeskriget. Efterkrigstidens politiska balansgång i förhållande till Sovjetunionen dämpade även den segrande sidan och tystnaden lade sig över landet. Den bröts ordentligt först 1957 i och med Juhani Paasivirtas Suomi vuonna $19 I 8^{41}$ och Hannu Soikkanens doktorsavhandling 196r Sosialismin tulo Suomeen. ${ }^{42}$ Bondestams specialområde blir tiden

39. Hufvudstadsbladet I5/II 1979 .

40. Vasabladet $15 / 2$ I 979.

4I. Juhani Paasivirta, Suomi vuonna I9I8, Porvoo: WSOY I957.

42. Hannu Soikkanen, Sosialismin tulo Suomeen: ensimmäisiin yksikamarisen eduskunnan vaaleibin asti, Porvoo: WSOY r96r. 
från sekelskiftet fram till I9I8, den tid då arbetarrörelsen exploderade till en massrörelse. Hon följer två tydliga linjer i sina historiska arbeten: att lyfta fram den finlandssvenska arbetarklassen och att se på historien ur folkets synvinkel. Dessa linjer löper ofta parallellt.

Den finlandssvenska arbetarrörelsen har för det mesta varit liten. I de svenska regionerna har storebror Svenska folkpartiet haft ett ständigt övertag, ett faktum som - enligt Bondestam - är sociologiskt obegripligt. I text efter text återkommer hon till frågan varför arbetarrörelsen inte attraherat den finlandssvenska arbetar- och småbrukarbefolkningen. Hennes svar är språkfrågan. I Stadens bröd lät hon Mia och Jonas resonera kring hur språkidentiteten krockade med klasstillhörigheten. I historiken över Finlands svenska arbetarförbund, Som en stubbe i en stubbåker, skriver Bondestam:

Den sociala radikalism som via finskhetsrörelsen redan på I80o-talet aktiverade finnarna, såg man inte många spår av bland landets svenskar. När en nationalitetsrörelse så småningom uppstod också bland dem, tog den inte heller sikte på några sociala mål. Den såg som sin främsta uppgift att sammansvetsa en hotad språklig minoritet, och då var det föga opportunt att peka på de sociala klyftor som skiljde fattig och rik, allra minst som de flesta rika var att finna just bland svenskarna. Så mycket mer framhävdes det gemensamma, framför allt språket, men gärna också 'vår urgamla svenska kultur', som tycktes ha en mäktig förmåga att förgylla allt som var svenskt, bara det var tillräckligt gammalt. ${ }^{43}$

För Bondestam var det en livsuppgift att motbevisa uppfattningen om Svenskfinland som enhetligt borgerligt. En metod för henne att driva denna tes var att skriva folkets historia, inte herrskapets. Den historieskrivningen saknades då Bondestam forskade i historia på I960- och 1970-talen. I en intervju säger Bondestam:

När man som jag skriver om kontroversiella ämnen, också i mina historiska arbeten, är man hela tiden på jakt efter konventionella

43. Anna Bondestam \& Alf-Erik Helsing, Som en stubbe i en stubbåker. Finlands svenska arbetarforbund I899-1974, Helsingfors: Finlands svenska arbetarförbund I978, s. I8. 
påståenden, som man vill sticka hål på! Ibland var den konventionella bedömningen om hur saker och ting gått till förstås riktig, men det lönar sig att vara skeptisk. ${ }^{44}$

Att hennes arbeten uppvisar en politisk tendens nekar hon inte till. Vem är helt fri från värderingar, undrar hon:

En författare som påstår sig vara opolitisk är vanligen en som oreflekterat omfattar de allmänna åsikter och värderingar som präglar det samhälle han lever i. Det betyder i klartext, att eftersom vi fortfarande lever i ett borgerligt samhälle så är han politiskt sett en borgare och det präglar nog ofta det han skriver. ${ }^{45}$

Sin främsta insats som populärhistoriker gör hon i historiken över den lilla, framgångsrika svenska arbetartidningen Arbetet $^{46}$ som utkom i Åbo åren I909-I9I8. Studien av den radikala lilla tidningen fungerar som en tidsspegel. Bondestam ser en styrka i att olika röster kommer till tals. Som introduktion till kapitlet om tidningens linje och innehåll skriver hon:

Det som i fortsättningen följer, bör inte heller betraktas som ett försök att ge en repetitionskurs i vårt lands dåtida historia. Det är bara tidningen Arbetets version av den, och den var på sitt sätt något ensidig. Vilket å andra sidan inte behöver betyda, att den är så mycket oriktigare än den version som vi får oss till livs i våra kurs- och läroböcker. Boken om vårt land kan säkert skrivas på många olika sätt. ${ }^{47}$

Hösten I9I7 var den svenska arbetarrörelsen aktivare än någonsin. Medlemsantalet i de svenska arbetarföreningarna uppgick till närmare Io ooo - en tiodubbling av medlemsantalet skedde 1916-1917. Arbetet hade aldrig förut haft så många prenumeranter; I9I8 var antalet I2 500 . Långt ifrån alla svenskar i Finland befann sig på den vita sidan av

44. Samlingen Finlandssvenska författarintervjuer, SLSA ro99, SLS arkiv, Helsingfors. 45. Ibid.

46. Anna Bondestam, Arbetet, Skrifter utgivna av Svenska litteratursällskapet i Finland (SSLS) nr 426, Helsingfors: SLS r968.

47. Ibid., s. 99. 
fronten. Det kommer Bondestam åt att visa i historiken om Arbetet. I april I9I8 är tidningens saga all. De vita trupperna intar Åbo och redaktionen flyr staden. Bondestam avslutar historiken med att redogöra för en av orsakerna som drivit henne att författa texten. Hon lyfter fram det faktum att det socialdemokratiska ledarskiktet efter I9I8 blev föremål för en - som hon kallar det - ond mytbildning som man ännu femtio år senare kan se reminiscenser av. Med sin bok om Arbetet och människorna bakom den vill hon bidra till att teckna en mer nyanserad och verklighetstrogen bild av vad som drev åtminstone vissa kretsar bland de röda till upproret år $1918 .{ }^{48}$

\section{JAKOBSTAD 1918}

En rad slumpartade kontakter i slutet av I980-talet leder in den då snart 8o-åriga Bondestam på att skriva det som kommer att bli hennes sista bok: Jakobstad, vintern I9I8. Pietarsaaren talvi I9I8 (I990). Hon återvänder igen en gång till år ı19 för att ge en bild av händelserna i Jakobstad under ödesåret. Jakobstad låg I9I8 långt inne på de vita truppernas territorium. Det röda motståndet var svagt - men med Bondestams dokumentation i Klyftan i minne står det klart att arbetarrörelsens folk hotades och pinades under hela året. Det är en enskild händelse som mer än något annat kommit att prägla historieskrivningen om I9I8 i Jakobstad: avrättningen av sex röda och länssekreterare Jääskeläinen vid tobaksfabriken, mitt i stadens centrum, natten mot den 2 mars.

Händelsen har flera starkt provokatoriska drag, som redan i sig kan ha bidragit till att hålla dess minne levande. Men väsentligast är i alla fall, att den aldrig blev uppklarad. Strax efteråt inskränkte sig klarläggningen till en kort officiell kungörelse vari det hette, att de avrättade hade dömts för landsförräderi och stämplingar mot landets lagliga Regering i förbund med den ryska arvfienden. Men mer än så blev det aldrig. ${ }^{49}$

48. Ibid., s. $35^{2}$.

49. Anna Bondestam, Jakobstad, vintern I9I8. Pietarsaaren talvi I9I8, Jakobstads museums publikationer nr 22, Jakobstad: Jakobstads museum I990, s. 5 . 
Bondestam rekonstruerar en version av det skedda. Hon redovisar för vilka källor och vilka antaganden hon bygger sin konstruktion på och överlåter åt läsaren att bedöma trovärdigheten. I slutet av boken knyter Bondestam an till sina egna minnen och sin skönlitterära beskrivning av händelserna. Hon har intervjuat August Videman, som har personliga minnen från vårvintern I918. Videman kan bekräfta ett gammalt rykte om att det ursprungligen var åtta personer som dömdes till döden - men en av dem lyckades fly. Flyktingen sökte sig hem till familjen Videman där han fick gömma sig tills han flyttades till riksdagsman Elfvings sommarstuga på Östanpå, det vill säga hem till Bondestams föräldrar.

I Klyftan utspelar sig flera scener kring hur Ruts föräldrar gömde en man som flytt för sitt liv undan de vita. Det torde - på basen av vittnet August Videman - ha varit den person som flydde undan sin dödsdom i mars I9I8.

I Jakobstad, vintern I9I8 skriver Bondestam att Videmans uppgifter är omtumlande för henne personligen - på basis av hans beskrivningar kan hon sluta sig till att mannen som flydde undan avrättningen var Antti Järvinen, vaktmästare på den finska arbetarföreningens lokal, kallad"Talo": Videmans berättelse stöder alltså ryktet om den åttonde dödsdömda som lyckades fly, och min berättelse kan kanske upplysa om vem den mannen var. Kanske - alltså, för något bevis som skulle hålla i alla väder har jag inte." ${ }^{0}$

Den tvåspråkiga boken Jakobstad, vintern I9I8. Pietarsaaren talvi I9I8 utkom I990. Den möttes av ett brett intresse. I Vasabladet skriver Dennis Rundt: "De så kallade händelserna I9I8 var länge ett känsligt kapitel i Jakobstad. Ännu på 6o-talet fick till exempel samlyceisterna bara en selektiv insyn i den tidens lokala historia." ${ }^{51}$ I Hufoudstadsbladet recenserar Jakobstads Tidnings tidigare chefredaktör Anders Huldén: "Anna Bondestam, 83 år, har åstadkommit ett beundransvärt, ytterst välskrivet historiskt forskningsarbete kring en händelse som i årtionden varit mer eller mindre ihjältigen, tabubelagd i Jakobstad - men absolut inte glömd." ${ }^{52}$ Det allra märkligaste i den här saken, skriver

5o. Ibid., s. 83 .

51. Dennis Rundt, "En bit närmare sanningen om händelserna i Jakobstad I9I8", Vasabladet I4/IO I990.

52. Anders Huldén, Hufoudstadsbladet 30/12 I990. 
Huldén, är kanske att det har dröjt 70 år tills en seriös forskning kring detta sekels mest uppskakande händelse i Jakobstad har kommit igång - trots en stor kår av flitiga och kunniga hembygdsforskare. Av dunkla traumatiska orsaker har det tydligen bjudit emot att befatta sig med just denna fråga. I Helsingin Sanomat skriver Jukka Rislakki att historiken är anspråkslös i ordets positiva bemärkelse, att författaren förringar det arbete hon giort och sina uppgifter, medger brister och hoppas att andra forskare kunde ta vid där hon slutat. Trots detta, skriver Rislakki, har Bondestam presterat en klar och koncis, objektiv krönika där vissa gamla, felaktiga uppgifter korrigeras. Rislakki noterar att Jakobstadsborna själva undgår fällande domar i Bondestams historik - författaren än försiktig och finkänslig, kanske till och med i överkant. Hon kunde säkert, om hon velat, ha hittat färgstarkare och mer blodiga versioner och berättelser av det som skett, och vem som varit skyldig till vad. ${ }^{53}$

Jakobstad, vintern I9I8 blir Anna Bondestams sista verk; hon är 83 år då den utkommer. Hon sluter en cirkel som börjar och slutar i Jakobstad. Tjugonio år ung skojade hon friskt med småstadsmentaliteten på Röllebys gator. Drygt 50 år senare är hon en auktoritet $\mathrm{i}$ position att med helt andra förtecken röra om i småstadsgrytan och lyfta på locket kring länge nedtystade skeenden.

\section{ÅR 1918 SOM EN RÖD TRÅD GENOM LIVET}

Den socialdemokratiska ideologi som Anna Bondestam bar med sig från föräldrahemmet fick sina mest tydliga konturer år 1918. Upplevelserna som hon under krigsvintern delade med sina föräldrar präglade henne för livet och var avgörande för den väg hennes författarskap kom att ta. Verkningarna på ett rent psykologiskt plan är lika uppenbara. Ända från barndomsåren byggde Bondestam upp en bild av sig själv som den fula ankungen. Den som inte passade in på läroverket, på universitetet, i de bildade kretsarna i huvudstaden, bland författarkollegerna eller hos de borgerligt sinnade finlandssvenska läsarna och kritikerna. I diktsamlingen Jordnära (1972) skriver hon i "Varuoch självdeklaration": "Och så bjöd man till / pliktskyldigast / fast

53. Jukka Rislakki, Helsingin Sanomat $\mathrm{II} / 9$ 1990. 
anlagen var små / för leran var sån som / det lättare blir rädslor av / än trots ..." ${ }^{54}$ Dessa rädslor kämpade Bondestam emot i hela sitt liv. Allra tydligast har de blottats i förhållandet till författaridentiteten. Ändå gav hon aldrig upp. Hennes böcker är bevis på att hon ständigt besegrade sig själv.

Socialdemokratin, särskilt i dess finlandssvenska tappning, fanns med på ett hörn i nästan hela hennes litterära produktion på tio skönlitterära verk och sju populärhistoriska. Året I9I8 ligger som ett raster över hela författarskapet: uttalat i populärhistoriska verk som Aland vintern I9I8 (1972) ${ }^{55}$ och Jakobstad, vintern I9I8. Pietarsaaren talvi I9I $8^{56}$ och mera som en underström i romaner som Lågt i tak om arbetarklassungdom eller novellsamlingen Enskilt område som bland annat undersöker känslor av utanförskap. Anna Bondestam använde sitt politiska perspektiv som en ögonöppnare för läsaren; hennes sätt att gestalta världen, i både fakta och fiktion, utgick från en arbetarsynvinkel som hon menade gav nya dimensioner och öppnade för möjligheter till konstnärligt intressanta resultat.

I sin författarroll stod hon dock ständigt på ena sidan av en klyfta som är djupare än många andra - klyftan till modernisterna. Modernismen hade, under de årtionden Bondestam skrev skönlitterärt, ett starkt grepp om den finlandssvenska litteraturen. För Bondestam var innehållet $\mathrm{i}$ texten det viktiga - inte formen. Hennes syn både på modernismen som litterär stil och det hon kallade "de modernistiska, manliga författarkotterierna" förblev fördömande. ${ }^{57}$ Hon ironiserar över modernistikoner i en intervju:

Den modernistiska prosan kan vara oerhört vacker. En gång slog jag upp en sida i boken Modern finlandssvensk prosa alldeles av en händelse och tänkte: Vem skriver så här vacker prosa? Det var Rabbe (Enckell). Man märkte språket, men vad det handlade om spelade inte så stor roll. ${ }^{58}$

54. Anna Bondestam, Jordnära: Dikter, Helsingfors: Holger Schildts förlag 1972, s. 7 .

55. Anna Bondestam, Åland vintern I9I8, Helsingfors: Holger Schildts förlag 1972.

56. Bondestam, Jakobstad, vintern I9I8. Pietarsaaren talvi I9I8.

57. Se vidare Heikkilä, Anna Bondestam, s. I75.

58. Samlingen Finlandssvenska författarintervjuer, SLSA ıo99, SLS arkiv, Helsingfors. 
Ironi kan vara ett sätt att försöka skapa distans men det finns tydliga drag av bitterhet $\mathrm{i}$ tonen, då Bondestam diskuterar varför hennes karriär som romanförfattare tog slut i96o:

Jag kände inte att jag har en läsekrets. Nog finns det väl med som ingrediens till att jag slutade skriva efter Stadens bröd. Att jag tyckte att jag skrev som i ett tomrum. Men jag har hela tiden varit på det klara med att jag skulle ha kunnat ha en läsekrets. Men jag har ju valt att skriva kontroversiell prosa, rent politiskt. Och där har jag ju hela den finlandssvenska mentaliteten mot mej. ${ }^{59}$

Bondestams upplevelse av att befinna sig i marginalen på den finlandssvenska litterära scenen lyser tydligt fram i intervjuer och i hennes egna föredrag. ${ }^{60}$ Hennes position på den litterära kartan i Svenskfinland diskuteras ingående av Svenolof Karlsson i en artikel i Horisont år 1984. Karlsson tar fasta på bland annat recensionerna av romanen Klyftan och ger stöd åt Bondestams känsla av att vara förbigången:

En sak framgår tydligt när man läser den kritik Anna Bondestam fått genom åren: man har i Svenskfinland inte förstått hennes skildringar. Hon är offer för en oförmåga i de litterära kretsarna att betrakta världen ur social synvinkel. Hon är offer för fixeringen vid modernismen. Hon har på sätt och vis avlivats utan att man sett vad man avlivat. Gång på gång har man i Svenskfinland ljudligt beklagat avsaknaden av författare som skulle skildra finlandssvenskt vardagsliv brett episkt - och inte sett att Anna Bondestam varit just denna efterlysta författare. ${ }^{61}$

Bondestams frustration kan tolkas som både klass- och könsrelaterad. I en antologi om kvinnliga proletärförfattare i Sverige, Vardagsslit och drömmars språk (I98I), behandlas problematiken:

59. Ibid.

6o. Se vidare Heikkilä, Anna Bondestam, s. I73-I76.

6r. Svenolof Karlsson, presentation av Anna Bondestam, Horisont 1984:4. 
De har tagit ett steg bort från sin klass, men oftast utan att ha fått ordentligt fotfäste i den litterära världen. Banden dit förblir sköra. Kanske är det därför proletärförfattarinnorna sällan tematiserar den konflikt som är ett viktigt tema hos de främsta manliga arbetarförfattarna: konflikten mellan ursprungsmiljö och författartillvaro. ${ }^{62}$

Den lätt sarkastiska syn och det tydliga avstånd som Anna Bondestam utvecklar i förhållande till en del "väsensfrämmande" författarkolleger liknar Moa Martinsons erfarenheter i Sverige. Ebba Witt-Brattström skriver, i ovannämnda verk, om Martinsons I930- och I940-tal:

\begin{abstract}
Moa kände sig aldrig riktigt hemma i författarkotterierna i Stockholm. Hon upplevde sig nonchalerad och sedd över axeln av de unga män som träffades för att sola sig i glansen av varandra. Hon försvarade sig genom att i sin tur se ner på dem: 'Jag vill ha med enkelt vettigt folk att göra och inte med denna sliskiga hjord av fjantar som skriver och skriver och är så estetiska att jag får magplågor' ${ }^{63}$
\end{abstract}

Samtidigt var Bondestam sträng vad gällde den litterära kvaliteten - folklivsskildringar för folklivsskildringarnas skull var ingenting att sträva efter. I debatten om folksmak och finsmak under i940-talet, då förlaget Bros tryckpressar spottade fram så kallade folkliga romaner i tusental, valde Anna Bondestam i egenskap av litteraturrecensent tydligt sida - skildrare av folket som hon själv var. ${ }^{64} \mathrm{I}$ sin skarpa kritik av den så kallade bygdelitteraturen ställde hon sig på huvudstadskritikernas sida, emot provinsen och "folket". Från sitt helsingforsiska perspektiv formulerade hon i sin litteraturkritik liknande krav som senare Sven-Olof Högnäs, själv Bro-författare men också blivande Horisont-redaktör, nedtecknade i en artikel vid tiden för Svenska Österbottens litteraturförenings grundande:

62. Eva Adolfsson, Tilda Maria Forselius, Kristina Lundgren, Enel Melberg \& Ebba Witt-Brattström, Vardagsslit och drömmars språk: svenska proletärförfattarinnor från Maria Sandel till Mary Andersson, Enskede: Hammarström \& Åberg bokförlag I98I.

63. Ebba Witt-Brattström,"'Lita på en karl, man skulle ha stryk!'. Hela svenska folkets Moa - myten, människan och verket”, Eva Adolfsson et al., Vardagsslit och drömmars språk, s. I32.

64. Se vidare Heikkilä, Anna Bondestam, s. I24-I27. 
Målet bör vara att skänka de skrivintresserade en allsidig inblick i författarskapets vanskligheter, att öka självkritiken hos dem, som skriver genom att skärpa kravet på de alster som utges. Endast den vägen finns det chanser att få fram österbottnisk bygdelitteratur av god klass. ${ }^{65}$

I artikeln"Sprickor genom Svenskfinland"i Finlands svenska litteraturbistoria. Andra delen skriver Bror Rönnholm om bygdeskildringarnas roll i kampanjen för finlandssvensk identitet och sammanhållning:

Visserligen möter man skildringar av landsbygdsbefolkningens hårda arbete och villkor, men ideologin får också sitt i form av idealiseringar och idylliseringar av det sunda livet och de sunda människorna på landsbygden. Förlaget Bros utgivning på r940-talet kan ses som en sista utlöpare av denna kampanj. ${ }^{66}$

Bondestams egna småstadsskildringar skiljer sig bjärt från denna "ideologiskt lovvärda litteratur". Hon irriterades djupt av publikfriande bygdeskildringar och protesterade emot lovsånger över "den gamla, goda tiden". Bondestam hade lämnat Österbotten i mitten av I920-talet och bodde i Helsingfors i drygt 50 år. Hon ställde sig med den ena foten i den österbottniska myllan och den andra i de helsingforsiskt bildade kretsarna. Innehållet $\mathrm{i}$ hennes romaner luktade jordgolv och fattigdom, vilket matchade hennes egen jordnära inställning till tillvaron. Men hon hemföll aldrig åt nostalgi. Hon granskar sin hembygd med eftertanke.

Hon gick i otakt med det litterära uppvaknandet i Österbotten. Det som hennes österbottniska kolleger började kämpa för i och med grundandet av Svenska Österbottens litteraturförening år 1950 hade Anna Bondestam genomlevt - utåt sett med framgång - redan från början av sitt författarskap. Hon hade kämpat mot modernismens hegemoni, för litterärt kvalitativa bygdeskildringar och för att bredda litteraturens bild av Svenskfinlands sociologiska verklighet.

65. Sven-Olof Högnäs citerad i Bror Rönnholm,"Sprickor genom Svenskfinland", utg. Clas Zilliacus, Finlands svenska litteraturbistoria. Andra delen: Igoo-talet. Uppslagsdel, Helsingfors: Svenska litteratursällskapet i Finland 2000, s. 253.

66. Ibid., s. $257^{-2} 5^{8}$. 
Ser man till utgivning (Anna Bondestams böcker utkom alltid på Helsingforsbaserade förlag, främst Schildts), försäljningssiffror och erkänsla så lyckades hon väl. Däremot hade hennes självkänsla mått bra av stödet som de österbottniska författarna gav varandra i och med den litterära resningen i landskapet. Men hon var före sin tid, före de österbottniska författarnas tid.

Om Bondestam gått i otakt med det österbottniska litterära uppvaknandet gällde det samma för kvinnofrågan. Hon uppfattade sig aldrig som kvinnosakskvinna. Men hur skulle en Anna Bondestam - allergisk mot uppblåsta auktoriteter, konventionens patentfraser och med den kritiska livshållningen i blodet egentligen kunnat vara icke-feminist? Redan romanen Fröken Elna Johansson, ${ }^{67}$ som utkom år I939, är i all sin lågmäldhet en bok specifikt om kvinnornas ställning i samhället. Detta såg bland annat recensenten Viola Renvall som skriver i Tammerfors Aftonblad att boken "borde delas ut som friexemplar till dem, som ha något att göra med kontorsflickors små löner" ${ }^{68}$ Trots att Bondestam aldrig har betraktat sig som en feministisk författare accepterar hon en feministisk läsning av sina romaner. ${ }^{69}$ Den belysning som hennes böcker ger kvinnors åsidosatta position i samhället har däremot inte varit en medveten strävan.

\section{DEN STÄNDIGA OUTSIDERN}

I en utomstående iakttagares ögon finns det inga skäl för en Anna Bondestam - senast efter prisregnet med start på ig6o-talet - att betrakta sig som en outsider i den finlandssvenska litteraturen. Redan I963 hade Nils-Börje Stormbom i en artikel i Horisont slagit fast att Bondestam utan tvekan kan kallas:

en av våra främsta prosaister genom tiderna. Som litterär konstnär är Anna Bondestam en av dem vi länge hade för få av i Svenskfinland och alltjämt inte kan ståta med något överflöd på. Hon förenar i en

67. Anna Bondestam, Fröken Elna Johansson, Helsingfors: Holger Schildts förlag I939. 68. Viola Renvall, "Fröken Elna Johansson", Tammerfors Aftonblad ı/ı I940.

69. Samlingen Finlandssvenska författarintervjuer, SLSA ro99, SLS arkiv, Helsingfors. 
lycklig kombination social och psykologisk realism och visar i de flesta av sina böcker en skicklig behärskning av uttrycksmedlen. ${ }^{70}$

Men ingen yttre framgång tycktes vara tillräcklig som bekräftelse för Bondestam. Den känsla av utanförskap som grundmurats under decennier blev hon aldrig fri från. Däremot blev hon försonligare med åren. Samhällsutvecklingen och den gryende välfärdsstaten bidrog till att de skarpaste motsättningarna mellan de ideologiska lägren långsamt blev suddigare i kanterna. Våren i96r producerade Finlands Rundradio en serie där finlandssvenska författare och intellektuella talade kring temat Jag lever i republiken Finland. Anna Bondestam medverkade. Söderströms förlag publicerade bidragen i en bok med samma titel. ${ }^{71}$ I sitt anförande ger hon en bakgrundsteckning till sin (tidigare) motvilja mot allt som kallas fosterländskt. Hon söker orsakerna till detta i sina erfarenheter som barn i en röd familj under inbördeskriget och som socialdemokrat under Lappoåren. I dag, skriver hon, trivs hon dock ganska bra i det så kallade fosterlandet och ger en förklaring:

Det är det andliga klimatet som har förändrats. Det har helt enkelt blivit tolerantare. Kanske kan det förefalla egendomligt att påstå något sådant i en tid, som enligt många karakteriseras av en allt bittrare politisk maktkamp både mellan och inom partierna, men trots allt gör jag det, och jag gör det i min egenskap av vanlig enkel medborgare, som bättre känner till allmänatmosfären än väderleken i de politiska kretsarna. Och det är nu en gång för alla så, att i ett relativt välmående samhälle är allmänatmosfären fredligare och försonligare än i ett samhälle med svåra sociala lyten. Framför allt accepteras demokratin skäligen osökt av de flesta som det naturliga politiska tillståndet, man ser följaktligen inte oförsonliga fiender i alla, som inte tillhör samma parti som man själv, och använder inte i tid och otid fosterlandet som tillhygge för att krossa dessa fiender. ${ }^{72}$

70. Nils-Börje Stormbom,"Anna Bondestam", Horisont I963:2.

71. Anna Bondestam et al., Jag lever i republiken Finland, Helsingfors: Söderström \& C:o Förlagsaktiebolag I96I.

72. Ibid., s. I3. 
Anna Bondestams författarskap har uppmärksammats i sju avhandlingar pro gradu och i ett stort antal tidnings- och tidskriftsartiklar. Hennes författarskap har kortfattat behandlats i handböcker över finländsk och finlandssvensk litteratur. ${ }^{73}$ I Maria Lival-Lindströms (numera Lival-Juusela) doktorsavhandling i litteraturvetenskap ${ }^{74}$ ingår en undersökning av romanen Fröken Elna Johansson. Samma roman undersöks som en del av Eva J.Johanssons doktorsavhandling år 2017. ${ }^{75}$ Pia Heikkiläs biografi Anna Bondestam. Det röda Svenskfinlands röst (20I3) är den första heltäckande biografin över Bondestam. Denna essä baserar sig i hög grad på biografin.

73. Se t.ex. Ingmar Svedberg, Anna Bondestam - en skönlitterär socialskildrare i otakt med tiden, Alf-Erik Helsing et al. (red.), Eldsjälar. Personporträtt ur finlandssvensk arbetarrörelse, Helsingfors: Schildts 2000.

74. Maria Lival-Lindström, Mot ett eget rum. Den kvinnliga bildningsromanen i Finlands svenska litteratur, Åbo: Åbo Akademis förlag 2009.

75. Eva J.Johansson, Realismens röster. Kvinnliga kontorister i mellankrigstidens finlandssvenska litteratur, Åbo: Åbo Akademis förlag 2017. 